\section{EGRI Miklós}

\section{QUORSUM HOC PERTINEO DEFECTUS? -}

\section{A HIBÁZÁS ÉS A SZERVEZETI VISELKEDÉS ÖSSZEKAPCSOLÓDÁSA}

A hiba egy elvárt állapottól való eltérést testesít meg, ami nem jó. Érthetố módon a hibázás a teljesítményorientált szervezetek tagjai számára általában negatív. A cikkel a szerzố kísérletet tesz a hibázás és a szervezeti viselkedés kapcsolatában rámutatni arra, hogy a hibázás elkerülhetetlen, sốt kívánatos. A hiba szociológiai értelemben kerül feldolgozásra „egy bizonyos elvárt eredményállapottól való eltérés megállapításaként". A dolgozat részletesen végigviszi a hiba fogalmának dimenzióit és azok hatásait a szociológia fóbb rendszereire. A fejlódés egyik alapvetố elósegítójén keresztül, a hibakultúrán keresztül jut el a hiba és a szervezeti viselkedés összekapcsolódásához. A modern társadalom tagiainak egymástól való függósége és a hibák hatása nốtt. A szociológiai rendszerek eredményessége és a hibákhoz való viszonya fontos aspektus (1) zitivitására és bennük rejló lehetôségek kiaknázására épülnek.

Kulcsszavak: hiba, hibázás, hiba definíció, norma, hiba megítélése, elkövetô, konzekvencia, hiba dimenziói, deklarált norma, látens norma, hibatípusok, hibaelemzés, szankció, hibakultúra, prevenció, kísérlet, kockázat, szervezeti viselkedés, szervezeti tanulás

Mindenki találkozott már hibával az élet különböző te- : egy megszokott vagy kívánatos, azaz elvárt állapottól. rületein. Gondoljuk csak végig egy napunkat, s vegyük Ezt a nem megfelelôséget érzékeljük egy késốbbi időszámba mennyi olyan dolog, esemény történhet, ami- pontban külsố vagy belsó szemlélóként, s beszélünk re azonnal azt mondanánk valamilyen formában, hogy „hiba történt."

A teljesség igénye nélkül - a legegyszerúbbtól a bonyolultabbakig: az ébresztőóra nem ébreszt idóben, öltözködéskor leszakad egy inggomb, nem jön a busz hideg a kávé a számítógép nem tud bejelentkezni a há lózatba, az időszakos értékesítési eredmények jelentóen elmaradnak a tervezettól, haz liftben, s nem ériük el a szính

$\mathrm{Az}$ elóbbi pár példáról elmondhatjuk, hogy kellemetlen szituációkat teremtenek, s megfelelő racionalitást feltételezve, nem kívánjuk sem magunknak, sem másoknak. Kellő́ absztrakció alkalmazásával megállapítható, hogy az adott állapotok, illetve az adott események következtében megvalósuló állapotok eltérnek

" Egri Miklós, MBA, jogi szakokleveles közgazdász Siemens AG Global Shared Services Prosurement Mobility Logistics Event Managemen

mickeyegri@yahoo.co hétköznapi értelemben hibáról

A jog, mint a társadalmi együttélés elfogadott és formális szabályozó rendszere is definiálja a hiba foa következóképpen szerepel:

„Ptk. 305. § (1) Olyan szerződés alapján, amelyben a felek kölcsönös szolgáltatásokkal tartoznak, a köteleidópontjában nem felel meg a jogszabályban vagy a erződésben meghatározott tulajdonságoknak."

Vegyük észre, hogy a hiba jogi megfogalmazása is egy a korábban meghatározott és ebbő́l kifolyólag deklaráltan elvárt eredményállapot és a „hibás teljesítés" következtében megvalósuló eredményállapot nem megfelelősége alapján kerül meghatározásra.

A „hiba” pontos definiálásához az azt meghatározó dimenziók vizsgálatával juthatunk közelebb, melyek a norma, normától való eltérés mérése, a megítélés idôpontja, valamint minốsége, a hibát okozó vagy „elkövetơ” és a konzekvenciák (1. ábra). galmát. A polgári t örvénykönyvben a ,hibás teljesítés”
Hiba és dimenziói

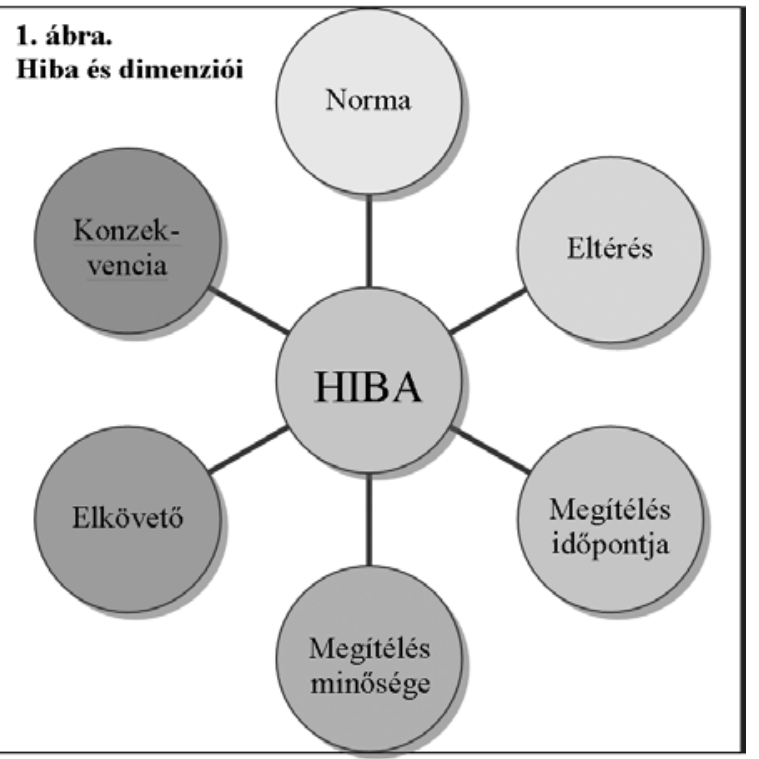

A norma

A norma alatt azt az eredményállapot vagy magatartás leírását értjük, amit egy bizonyos dologhoz, szituációhoz folyamathoz vagy cselekményhez, mint kívánatos zárendelünk, azaz elvárunk.

Manifesztált normák legkézenfekvốbb példája egy ország törvényei, melyek a társadalmi együttélés normáit határozzák meg, s a bennük meghatározott hatályon belül mindenkire egyformán érvényesek. Az ilyen típusú normák előnye, hogy deklaráltak, s így megfelelő felkészüléssel meg lehet nekik felelni. Példákat vég nélkül sorolhatunk a vállalati szektorból is, mint például: szabványok, vállalati utasítások, szabályzatok, célmegállapodások, eljárásmódok, folyamatleírások.

Latens normák esetében nincs normadeklaráció, vagy legalábbis nehezebben ragadható meg. Gondoljunk itt az erkölcsre és az etikára, amik gyakorlatilag szintén normák összessége és valahol a társadalmi együttélés hivatottak szabályozni, csakúgy, mint a törvények.

A deklaráció hiányát helyettesíthetik a különböző kultúrák, a kialakult szokásjog, illetve a ,,mögöttes norma", melybőll a konkrét norma levezethetô. Ehhez az etika két elméletét alkalmazhatjuk.

Az egyik, Immanuel Kant dentológián alapuló etika elmélete (Orend, 2000; Kelly, 2006), mely szeri egy cselekmény morális helyességének elengedhetetlen feltétele az, hogy a cselekvő feladatának és szerepének megfelelốn tesz. Továbbá nem a cselekmény következményeitôl lesz a helyes vagy helytelen, hanem a cselekvő indítékaitól (Kant, 1780). Esetünkbe úgy alkalmazható, hogy deklarált norma hiányában megvizsgáljuk a cselekvó feladatköréból adódóan, mit várhatunk el. Az így kapott eredményállapot vagy magatartás leírását rendlejük hozzá a szituációhoz, mint elvárt normát. A pedagógus feladata, hogy tanítsa és nevelje az ifuúságot. Ezert elvárható tốle, hogy a diákra rászól, ha illetlen vagy csúnyán beszél.

A másik, John Stuart Mill utilitarizmuson alapuló etikai doktrínája. Ennek értelmében egy cselekmény morális helyességét kizárólag a hasznossághoz valô hozzájárulás mértéke határozza meg (Mill, 1980). It a cselekmény eredményének hasznosśgát vizsgúljuk. Utilitar

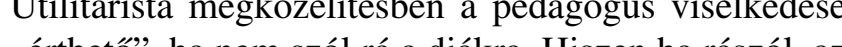
„écteg , ha non szól rá a diakra. Hiszen ha rászôl, az

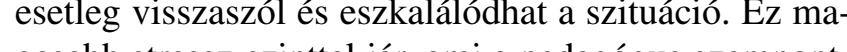
gasabb stressz-szinttel jar, ami a pedagogus szempontjâból negatív hasznosság, igy helytelen, s inkább nem szól a diáknak. A társadalom szempontjából azonban pozitív lett volna a hasznosság, ha mégis szól a diáknak. Vegyük észre, hogy a hasznosság relatív fogalom mértékét és nézőpontját tekintve (2. ábra).

Deklarált és latens normák

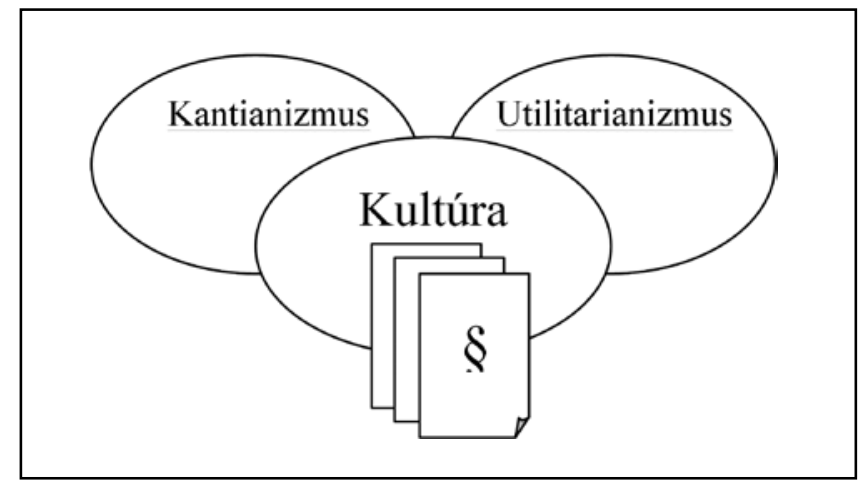

Összefoglalóan megjegyezhetjük, hogy a latens norma nem deklarált tulajdonságának megkerülésére használhatjuk a kantinizmuson és haszonelvúségen alapuló etikai elméleteket, melyek eredménye nem feltétlenül egyezik meg.

A fenti ellentmondást kiküszöbölheti a megítélố személyének a vizsgálatba való bevonása, mellyel késóbb foglalkozunk.

\section{Normától való eltérés mérése}

Adott norma, mint e hiba dimenzió által felvehetô értékkészlet egy adott eleméhez tartozó tulajdonságok megfelelőségének vizsgálatát tekinthetjük a normától való elterés mérésének. A mérés, ha mint objektív funkciót vesszük, alapvetően két értéket szolgáltathat: teljes megfelelőséget, illetve a megfelelőség hiányát. A rész- 
leges megfelelés és a megfelelőség részleges vagy telje hiánya alapvetôen komplementerek és a „,megfelelősé hiánya" értékhalmaz egészét adják, mint annak részha mazai. Feltéve, de nem megengedve a „részleges megfelelóség”, illetve „nem megfelelóség” külön értékkészleti elemek elfogadását, szembekerülünk a mérés objektivitásával. Tekintettel arra, hogy a „részlegesség” látszólag kimutathat arányos normamegfelelôséget, ami nem feltétlenül van arányban a norma teljes megfelelóségének hasznosságával és így kívánatosságával.

A fenti példák egyikén demonstrálva ez a követkepér ki. Áláában forró kávé vár zổé (elfogent és elvát állapot). Egyik vá reggeObgyil a for kávé helyett hideg kávé vár ránk. Objektiven mérve állapot tulajdonságát hibáról beszélünk, mert az állap egyik tulajdonsága, a hőfok nem felel meg az elvártnak Hiba annak ellenére, hogy elegendô a kávé mennyisége és a koffeintartalma. Amennyiben megengedjük a részleges megfelelőséget és további hibadimenziókat vonunk be a vizsgálatba, mint a megítélés minôsége, illetve a megfigyeló pozíciója, akkor eljutunk a szubjektív megítéléshez. Tegyük fel, hogy meleg nyári reggel van, $\mathrm{s}$ a hideg kávét is szeretjük. Lehet, hogy már régóta tervezzük kávés sütemény készítését, amihez fel is tudjuk használni a meglevő hideg kávét.

Ezért a normától való részleges eltérés jelentősége egy további dimenzió, a hiba megítélésénél bír fontossággal.

Hasonló következtetésre jutunk Niklas Luhmann „technikai” és „„ésszerứ”' rendszerek leírása kapcsán. A normák külonbözóségébôl adódó, a normátó való eltérés mérhetơségnek nehézségére hívja fel figyelmet. „A technikai rendszerek lényegében kauzálisan zártak. Gépek, melyek csak akkor múköonek, ha aramot kapnak és akkor is csak bizonyos vezérlókkel irányíthatók. Az ilyesfajta technikai vagy kauzális kapcsolódás előnyei mindenek elốtt a hiba felismerésének lehetôségében rejlik" (Luhmann, 2002: 95. o.). Ezzel szemben az „ésszerư” rendszereknél ez a fajta előny hiányzik és a hiba megítélése jobban függ annak megítélöjétől. Ha a rendszer jobban fúsen añón múködésben van, akkor mûkoudik, hogy hibátlan vagy sem, az a megfigyelóre es az altala képviselt jo teljesítmény vagy túlélési vagy bármi más

dardjára van bizva" (Luhmann, 2002: 96. o.).

Luhmann „ésszerü rendszerére volt példa a hideg kávé esete. A „technikai” rendszerekre a „,bennragadunk a liftben” vagy a „,számítógép nem tud bejelentkezni a hálózatba" hibaesetek felelnek meg. Az ilyen jellegú hiba elófordulásakor kellemetlen, hogy az ember nem a terveinek megfelelöen tudja végezni a dolgát. Ugyanakkor senki sem gondolta még komolyan, hogy örökre a liftben maradna, vagy a vállalati hálózatba egy hiba következtében soha többet nem tudna belepni, pontosan azért nem, mert a hiba felismerésének lehetôségére vezethetố vissza (3. ábra).

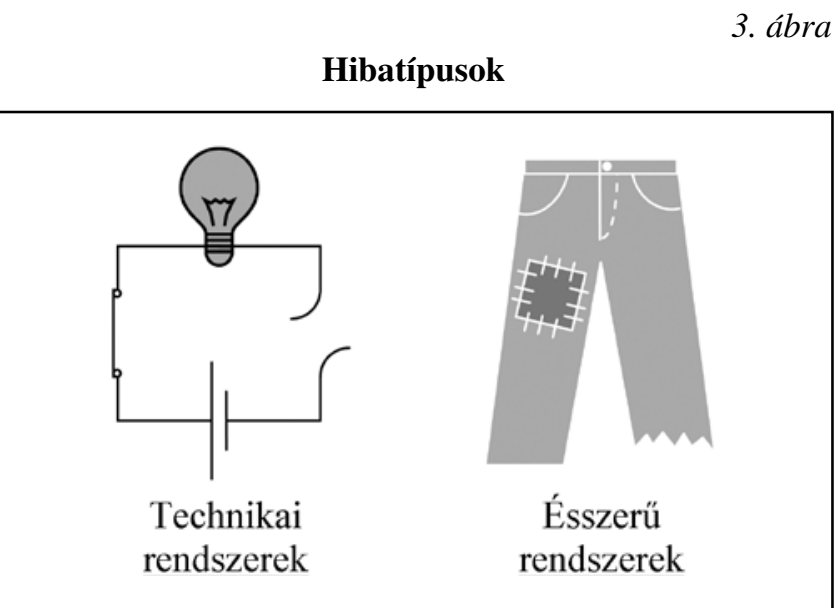

Az idó

A szakirodalomban általánosan képviselt álláspont szerint a hibáról csak akkor derül ki, hogy hiba, amikor már megtörtént. Ez egy kényszerú folyamat eredmé

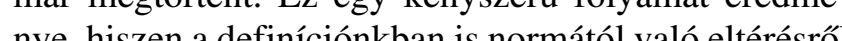

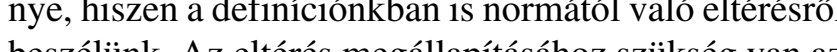
beszell eredményállapothoz tartozó normán túl az eredmenyallapot megfigyelhetó tulajdonságaira. Az eredményllapotot megvalósító magatartás, illetve folyamatnak kényszerúen a vizsgálat idópontját megelózóen meg kellett történnie, hogy annak eredményét megfigyelhessük, és azt a normával összehasonlíthassuk.

Humberto Maturana Romesin és Pille Bunnell jól világít rá a hiba retrospektív tulajdonságára a hiba keletkezesére vonatkozó megállapításukkal:

Egy hiba nem akkor keletkezik, amikor - a késốbbi megítélés szerint - ,hibásan” cselekedtünk, hanem mindig akkor, amikor annak tudatára ébredtünk, hogye colekményük helytelen volt (szemben a hazugságg e egy hau egy hazugság kimondásának pillanatában keletkezik)"

Az iménti hivatkozás a hazugság kapcsán felveti a hiba idődimenziójának esetleges „,ex ante” tulajdonságának vizsgálatát: hiba-e a hiba, ha már előre tudjuk, gy hiba lesz?

Ha tudni véljük, hogy magatartásunk által megvalósuló eredményállapot tulajdonságai nagy valószínúséggel elternek az elvárt tulajdonságoktól, döntést hozunk - az akkori ismereteink alapján - magatartásunk fennartásáról, módosításáról, illetve annak megszüntetéséról. Ioy a hiba nem a magatartás esetleges folytatásában valósul meg, hanem a magatartásunk esetleges megváltoztatására irányuló döntésünk során beszélhetünk késóbb esetleg helytelen döntésról, azaz hibáról.

Ezt támasztják alá a már korábban hivatkozott polgári törvénykönyv hibás teljesítésre vonatkozó rendelkezései is. A Ptk. 305/A szakasz első bekezdése szerint „ha a jogosult a hibát a szerzôdéskötés idópontjában ismerte, vagy azt ismernie kellett, a kötelezett mentesül a szavatossági felelósség alól". A fenti idézet egy késóbb tárgyalandó hibadimenziớ is érint, a hiba következményét. Most kizánóleg azidó komponent elenzem. A szerzódeskötés idópontjidó kon

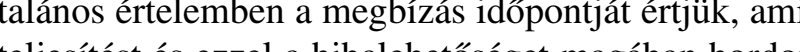
teljesítést és ezzel a hibalehetóseget magaban hordozz magatartást, illetve folyanatot negelözi. A mond második felében a torveny a cselekvớt mentesíti a hiba következményei alól, s ezzel gyakorlatilag a cselekvốt (kötelezettet) kiveszi a hiba elkövetói köréból. Így, ha a teljesítés eredményét leíró tulajdonságok nem felelnek meg a normát leíró tulajdonságoknak, a törvény nem tekinti hibának a cselekvő (kötelezett) szemszögébó . A hiba tekintetében új cselekvő lépett a teljesítésre kötelezett helyébe, mégpedig a megbízó (jogosult) azzal, hogy az eredeti hiba ismeretében és annak ellenére a megbízást kimondta. Döntésének helyességét abban az idốpillanatban - racionális döntéshozást feltételezve -

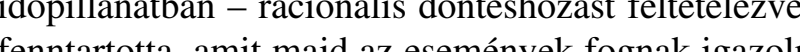
ak igazolni. is igaz, s az „ex ante” tulajdonságát kizárhatjuk.

\section{Az ,elkövetô’”}

Egy adott magatartást megvalósító, illetve egy eredményállapotot létrehozó személy a hiba elkövetôje, amennyiben a magatartás, illetve az eredményállapot az elvárt normától eltér. A továbbiakban a hiba elkövetóje, mint elkövető szerepel, ami nem felel meg a büntetốjogi értelemben vett elkövetőnek. Hogy van-e elkövetố, a hiba körülményeinek vizsgálata szïkséges. Reingar Kess a hibajelentések elemzéséhez használt struktúrájảban magát a hibát a szituació, ok és konzek

Amennyiben az okok közé tartozik a fenti magatartás, illetve cselekmény, úgy annak megvalósitója a hiba elkövetője is egyben. Ha az okok halmaza csak ezt az egy elemet tartalmazza, akkor beszélhetünk egyéni elkövetőról. Elképzelhető, hogy nem csak egy elkövetői magatartás része az okhalmaznak, ilyenkor többes elkövetésról beszélünk. Ha a többes elkövetés elkövetôi egymástól függetlenül cselekedtek, akkor az egyik elkövetố cselekménye a másiknak körülménye, a fent hivatkozott hibaelemzés (Kess, 2004) terminológiaja

\section{VEZETÉSTUDOMÁNY}

szerint, szituáció. Amennyiben az elkövetốk összehanoltan vagy egymás cselekményére építve követik el a ibát, a tôbbes elkôvetés egy speciális esetéról, a csoortos elkövetésról beszélünk

A büntető törvénykönyv (1978. évi IV. törvény) 137. szakasz 13. bekezdése szerint „,csoportosan követik el a búncselekményt, ha az elkövetésben legalább három személy vesz részt".

A hiba elkövetôinek körét a szociológia egyén, csoport, szervezet és társadalom tengelye, mint a szociológia legfontosabb szintjei mentén vizsgáljuk tovább.

Birgit Dechmann és Christine Ryffel szerint egy szervezet is egy speciális csoport, azzal a jelentôs küönbséggel, hogy többnyire hosszabb időre szervezőik, egy cél elérésére jön létre és saját struktúrával renlkezik (Dechmann - Ryffel, 2006).

A szervezet és a témánk, a hiba között lehetséges apcsolat meglétét támasztja alá a büntető törvényoönyv idevonatkozó értelmező rendelkezései. Az elóbb már hivatkozott szakasz 8 . bekezdése szerint bünszervezet a „három vagy több személybớl álló, hosszabb idôre szervezett, összehangoltan múködő csoport, amelynek célja ötévi vagy ezt meghaladó szabadságvesztéssel büntetendő szándékos bű́ncselekmények elövetése" Vegyük észre, hogy az összehangoltan múödó csoport feltétele a sajút struktúra İgy az elméleti c a jogi defińció megegyez. Szeretném kiemélet. 俯 veto, , ekmény minősítésére szerepelteti.

Ez is alátámasztja azt a nézetet, hogy egy szerveze nem lehet egy hiba elkövetóje csak azok tagjai.

A társadalom mint a szociológia egyik központi fogalma és a hiba kapcsolata nem feltétlenül kapcsolódik a vezetés-szervezéstan vizsgálódási körébe, ezért csak roviden érintem a teljesség kedvéért.

A hibaelemzés struktúrája

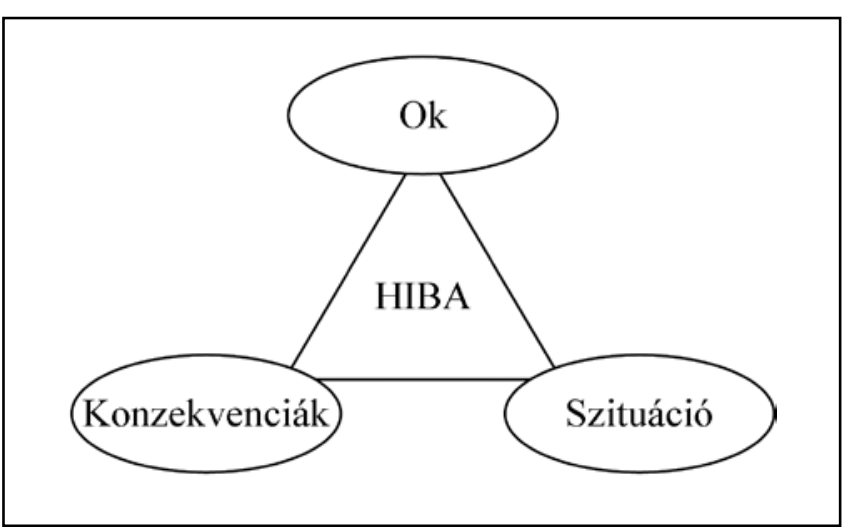

Forrás: Kess, 2004: 20. 
Ferdinand Tönnies társadalomdefiníciója a közösségbő́l indul ki. Egy közösséget a kölcsönös megbízás, emocionális kötődés és homogenitás jellemez a társad lommal szemben, amiben a szereplók mindegyike egyé ni célokat követ, melynek eredményeképpen a társad lomban az egyének között csak laza kapcsolat alakul ki.

A társadalomban lévő egyének egyéni céljai és egymásközti laza kapcsolatai miatt nem lehet a társadalomról, mint a hiba elkövetốjéról beszélni. Ezt támasztja alá a második világháború alatt kiadott, nemzetközi és jogi megítélés szerint erôsen vitatott Beneš-dekrétumok A dekrétumok a cseh társadalom egy részét nem konkÁt cselekményck személyes elkövetészét nem kon rét cselekmények szemétyes elkövetése miatt, hane 2003). Cikkem vonatkozásában ez a következóképpen 2003). Cikken vonakozásában ez a következóképpen értendô: a Beneš-dekrétumok nemzetiségeket határoztak meg, mint egy korábbi hiba elkövetóit. Valószín azért, mert a valós elkövetók is ehhez a nemzetisége hez tartoztak, ami teljes mértékben elfogadhatatlan.

\section{A hiba megítélése}

A hiba a megítélés szempontjából relatív. Egy magatartás, illetve egy bizonyos eredményállapot helyessége függ a megítéló személyétől.

Anja Mensching plasztikusan fejezi ki a hiba megítélőjének személyét a „címkézô” (Mensching, 2004: 47. o.) (5. ábra).

Címkék

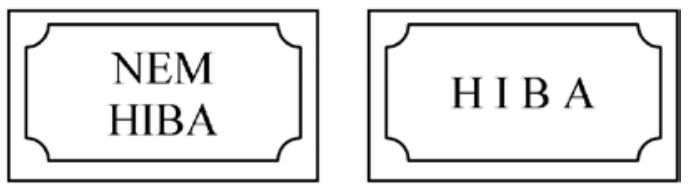

Átvitt értelemben a „címkézô" értékelésének megfelelően ellátja az eredményállapotokat, illetve magatartásokat az egyszerúség kedvéért ,hiba" vagy , nem hiba" tartalmú ,címkékkel".

Egy eredményállapot különböző megítélók szempontjából lehet egyidejúleg hiba, normával megegyez vagy egyik sem, azaz semleges, attól függóen, hogy a „címkézô” mit tekint elvárt eredményállapotnak.

Vegyük indulópéldánk egyikét: ,az idôszakos értékesitési eredmények jelentősen elmaradnak a tervezettốl". Tekintettel arra, hogy a fenti példa már hibakén értékelt, induljunk ki „A” vállalat tízmillió eurós idôszaki árbevételéból, mint eredményállapotból.

Amennyiben a megítéló, illetve az eredményt értékelő korábban célul túzte ki számunkra az adott idôszakra elérendố 15 millió eurós árbevételt, úgy az elért eredmény hiba. A versenytárs, „B” vállalat értékesítési igazgatója nagy valószínúséggel ezt az eredményt po-

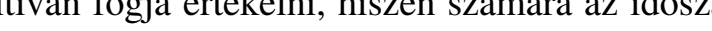
„A" vállalat megelőzése volt, ami sikerült az idôszakos 2 millió eurós árbevétellel.

Egy magánszemély, aki sem közvetlenül, sem közvetve nincs kapcsolatban „A” vállalattal, a tízmillió eurós időszakos árbevételt semlegesnek fogja értékelni. Vegyük észre, hogy „A” vállalat szemszögébő́l a hiba „B” vállalat szemszögéből lehetôségeket rejt. Erre mutat rá Jack Welch és Suzy Welch a roncsautó" aszszociációval. Egy autób toenen összetört autó az autó

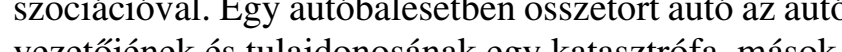
vezén ne roncsot megveszik, újJaépítik és ertékesítik, vagy alkatrészeire bontják, és úgy értékesítik, vagy akár arra az értékláncra, amelyik a roncsautónak a helyére egy új uutót termel (Welch - Welch, 2005)

Egy eredményállapot relatív értékelésének másik példájára világít rá Peters: „Mindenki ismeri Adolf Hitler festőmúvész történetét. Minden bizonnyal tehetséges festőmúvészként jelentkezett a Bécsi Múvészeti Akadémiára. A felvételi vizsgája nem volt eredményes. Ugy tünik mégsem volt tehetséges. Majd politikus lett. Lehet, hogy a felvételi vizsgabiztosnak nem is kellett (Petna 2004: 15. o.) A koŕbon részletesen tárgyalt kantiniz. ó

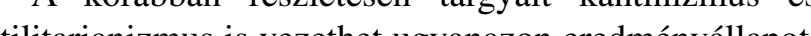
utilitarianizmas is vezethet ugyanazon eredmenyallapot, illetve magatartás tekinteteben kullóno értekeléshez, hiszen a normát másképp vezetí le a két irányzat. Vegyük észre, hogy ebben az esetben a hiba relativitása nem az értékelố személy különbözőségében, hanem az értékeléshez használt megközelítés különbözőségében rejlik.

Lehet-e az értékelő személyétól függetleníteni a hibát? Tekintettel arra, hogy a törvények alkalmazásában a relativitás nem megengedett, azaz mindenkire egyformán érvényes, vegyük ehhez a vizsgálathoz a társadalmi együttélést szabályozó, általánosan elfogadott s mindenkire kötelező érvénnyel bíró nemzeti törvényeket. Ezen belül is a hibás" magatartásokkal leginkább foglakoź, már a "nabozot bïntetó törvénykönyv 29. .

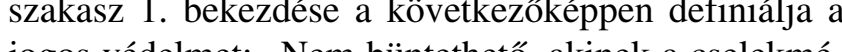
jogos vedel. aye a saját, illetóleg a mások szemelye, javai vagy közêk ellen intézett, illetôleg ezeket kozvetlenül fenyegetố jogtalan támadás elhárításához szükséges."

A 30. szakasz 1. bekezdése alapján végszükség: „Nem büntethetố, aki a saját, illetốleg a mások személyét vagy javait közvetlen és másként el nem hárítható veszélyból menti, vagy a közérdek védelmében így jár el, feltéve, hogy a veszély előidézése nem róható a terhére, és a cselekménye kisebb sérelmet okoz, mint amelynek elhárítására törekedett." Mindkét szakasz mentesíti az elkövetốt a cselekmény büntetójogi következményei alól. Gyakorlatilag kiveszi a cikke értelmében vett (hiba) elkövetôi köréból. Ez azért lehetséges, mert a hiba megítélésénél nemcsak a kérdéses eredményállapotot létrehozó magatartás vizsgálata szükséges, hanem Kess hibaelemzó modellje (Kess, 2004) kapcsán már említett körülmények vizsgála is. Osszefoglalva megállapíthatjuk, hogy ha kiiktatjuk a „címkézô” személyéból fakadó relativitást, a köriilményekhez képesti viszonyítás továbbra is megmarad, mely nagymétćlken befolý́solhatja az pot vagy a magatartás megítélését.

\section{Konzekvenciák}

A konzekvencia latin consequi szóból származik melynek jelentése: követ. A konzekvencia egy tényállástekintettel annak létrejöttére, ami egy vagy több cselekmény, illetve tényállás nem feltétlenül kauzál megvalósulását vagy cselekmények kauzális konfigurációját írja le. Ha megtörténik „X”, kényszerúen, illetve nagy valószínüséggel „,Y” is meg fog történn

Jelen értekezésre vetítve: egy bekövetkezett eredményállapot, ami elmarad az elvárt eredményállapottól, bizonyos mértékben meghatározza a további cselekményeket, illetve eredményállapotokat, azaz a hib lekményeket, illetve erc

Ezt a hatást leírhatjuk annak irányultsága és az általa indukált eredményállapot mentén. A konzekvencia irányulhat önmagára a hiba elkövetőjére, környezetér (csoport, szervezet, társadalom), s indukálhat automatikusan bekövetkező további eredményállapotokat, valamint szükséges cselekményeket.

A két tengelyt a szankciók kapcsolják össze. Pozitív szankcio a jutalom, míg negatív a büntetés. A szankciók hozzárendelése történhet automatikusan vagy mesterségesen. Az utóbbi alkalmazása elösegíti a tanulási folyamatot (6. ábra). A konzekvenciák jelentőségére mutat rá Ulrich Beck Kockázati társadalom címú könyvében. A szerző arra hívja fel a figyelmet, hogy bizonyos, az ember által okozott katasztrófák hatásai szociális és földrajzi értelemben határtalanná válnak. „A bajt ki lehet küszöbölni, az atomkor veszélyeit nem." (Beck, 1986: 7. o.)

A konzekvencia, mint a hiba egyik dimenziója, vezet át címben feltett kérdésnek érdemi tárgyalásához: Mire jó a hiba?

\section{VEZETÉSTUDOMÁNY}

\section{iibakultúra}

Az ipari munkamegosztás és a hibázás jelentőségének összefüggését Emil Durkheim dolgozta ki Durkheim az erkölcsból és a társadalmi összetartásból indult ki. Úgy gondolta, hogy az iparosodás elôtti idốkben a társadalmak kozoos ertékek mentén maradtak fent, mint a vallás. Ugyanakkor a büntetések is központi helyet foglaltak el, melyek szerepe a közös értékekre és normákra való „emlékeztetés” volt. A késóbbi ipari társadalmak ilyen jellegü integrálása egyre inkább feleslegessé vált, ugyanis az integráció mechanizmus bépult a táradilombi mégedig az ipari munamegoszt́s formájóban. Az ipari munkm az osztás a tárolom tagiat egyre jobban függóvé tesz egymáś́l (Durne 1988). Ha ezt a gogoné tesz tet tovább visszïk, könnyen beĺt ezt a gondolatmenejelentősége egyre inkább nố. Míg az iparosodás elótti társadalomban egy jobbágy által elkövetett hiba hatása belátható körön belül maradt - családján és a földesurán kívül másra nem volt jelentôs hatással -, addig az ipari társadalomban egy hiba megtörheti a teljes termelési láncot, s hatással lehet annak minden résztvevőjére.

Igy nem csoda, ha a hibához a legtöbb ember ne-

gatív asszociációt társít. Mint tudjuk, a hiba egy elvárt állapottól való eltérést testesít meg, ami nem jó.

Ugyanakkor a konzekvenciákat tovább gondolva, rájövünk, hogy a hibázás kapcsán lehetôségek is keletkeznek. S nemcsak a kívülállók számára, mint azt Jack Welch „roncsautó” párhuzama sugallja, hanem a hibát elkövetố és konzekvenciáit elszenvedő részére is.

Ezen a ponton érdemes kitérni a hibakultúrára, min egy szervezeti kultúra szerves részére. Ahol emberek közösen dolgoznak, vagy egymás eredményeire építe-

A konzekvencia és a szankció kapcsolata

6. ábra

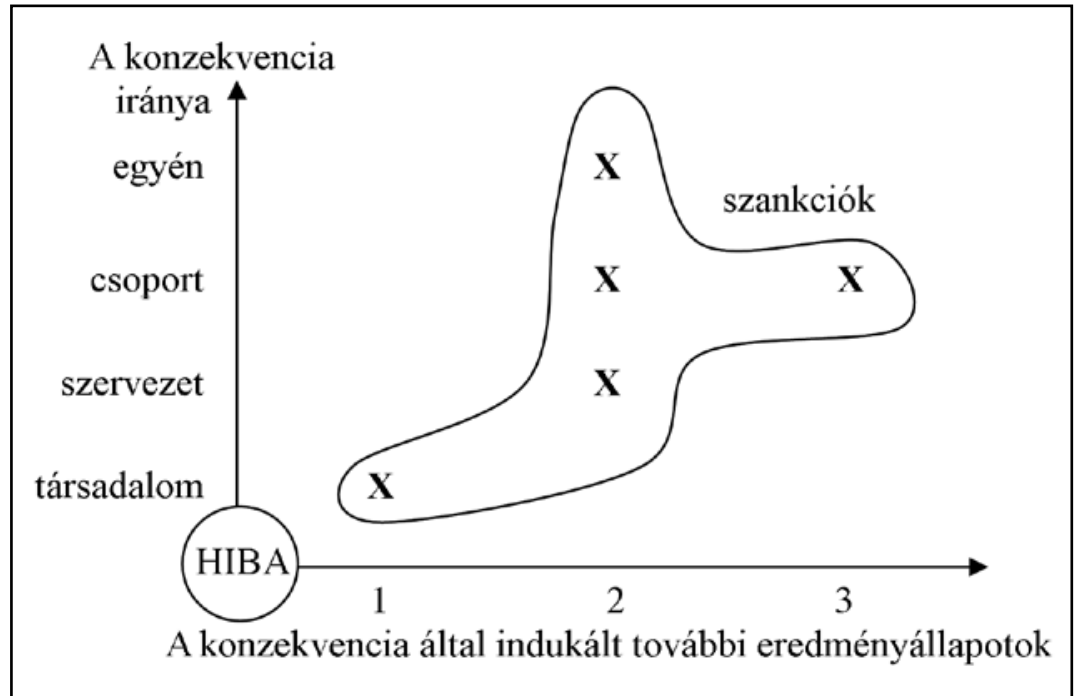


nek munkájukban, ott kialakul a hibákhoz való egyfajta hozzáállás, azaz egy hibakultúra.

A hibakultúra kifejezés a társadalom- és gazdaságtudományból származik, és azt jelöli, hogy mikép kezelik szociális rendszerek - a mi esetünkben szervezetek - a hibakockázatot, a hibákat és azok következményeit. Annak ellenére, hogy a hibakultúra kutatási terület többnyire az oktatás, vállalatok és nonprofit szervezetek területén összpontosul, további szociál s rendszerek is rendelkeznek hibakultúrával, mint például a család.

Így a pedagógia és vezetés-szervezéstan hibakultúra-kutatói azt vizsgálják, hogyan lehet egy hiba konstruktív? Hogyan lehet a hiba a tanulás forrása egy szervezetben? Hogyan lehet az innovációt elốremozdítani a hibák produktív kezelésével a vállalatoknál és nonprofit szervezeteknél. A hibakultúra lehetőségei a szigorú bamegelőzéstől a hibatámogatásig terjedhetnek.

Az iparosodás kezdeti hibakultúrája, mint a „hiba elkerülése" felülvizsgálatra került, s olyan kifejezések kerültek előtérbe, mint hibatürés, nyitottság hibára vagy hibatámogatás. Ennek eredményeképpen az 1990-es években a vezetés- és vállalatirányítás-tudomány egyik központi témája lett az innovatív tanulás és a tanulószervezet. Ebben az összefügoésben alakulhattak további szakterïletek, mint például hibakezhat́s, koc-

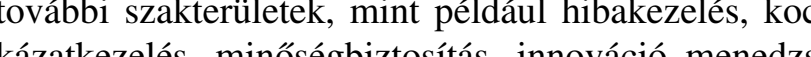

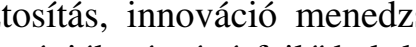
ment, melyek vállalati stratégiák részévé fejlódtek ki,
s ily módon a siker kulcsai is. y modon a siker kulcsai is.

A dolgozat elsô részében definiáltuk a hiba fogalmát, s áttekintettük lehetséges dimenzióit. A definíció értelmében a hiba nem más, mint eltérés az elvárttól, azaz nem kívánatos. Majd áttekintettük a hibakultúr történetét és a hibák jelentőségét, $\mathrm{s}$ arra a következtetésre kellett jutnunk, hogy hiába nem kívánatosak hibák, de azok lehetnek a jövőbeli sikerek kulcsai. Így nem maradt más hátra, minthogy áttekintsük mit érdemes kezdeni a hibákkal, s hogyan lehet a hibákat produktívan kezelni, s a hasznunkra fordítani.

Első lépésben bontsuk ketté az idődimenzió mentén elő́tt (pre-defectus), illetve utána (post-defectus).

\section{Pre-defectus}

Egy hiba bekövetkezése elótt kétféle hozzáállást különböztethetünk meg. Vagy úgy állunk a jövóbeli eseményekhez, hogy szeretnénk minél kevesebb hibát kezelni: prevenció, vagy úgy, hogy szeretnénk minél több hibát előidézni: experiment.

Az experiment, mint a hibához való hozzáállás olyan rendszerekben követendô, ahol a hiba bekövetkezés nagy valószínúséggel elenyészó negatív hasznosságot eredményez, szemben a hibából adódó pozitív lehetőgek várható hasznosságával.

Gondoljunk csak a középkori alkimistákra, akik az arany előállitását túzték ki célul. Mint tudjuk, nem jártak sikerrel. Eredeti céljuk tekintetében eredménytelenek voltak, hibáztak, de próbálkozásaik során sok hasznos információt generáltak a késóbbi fizika- és kémiatudományok hasznára. Másik példa lehet Amerika 1492-es felfedezése. Közismert, hogy Kolumbusz Kristóf a nyugati átiárót kereste Indiába, amikor felfeKristóf a nyugati

De történelmi jelentôségén túl nem nehéz rájönni, ogy az experimentális hibafilozófia a mai vállalatok śs intézetek egyik sarokköve a fejlódés és innováció területén. A fejlódés elképzelhetetlen lenne, ha mindig mindent ugyanúgy tennénk, mint a múltban. Nem véletlen, hogy az innovációs potenciálnak fontos indikátora a technológiai vezetô vállalatok, illetve a nemzetgazdaságok kutatás-fejlesztési kiadásai. Melyekbe beletartoznak az eredménytelen próbálkozások költségei, ami szinten az innováció ára (7. ábra).

A hibához való hozzáállá

\begin{tabular}{|c|c|c|}
\hline \multirow{2}{*}{$\begin{array}{c}+ \\
\text { Hibából } \\
\text { eredö } \\
\text { lehetôség }\end{array}$} & EXPERIMENT & \\
\hline & & PREVENCIÓ \\
\hline & U. & asznossága \\
\hline
\end{tabular}

A prevenció olyan rendszerekben lehet megfelelô hozzáállás, ahol a hiba bekövetkezése nagy valószínúséggel nagyobb negatív hasznosságot eredményez, mint a hibából adódó lehetôségek összege.

A hibaprevenció nem más, mint a cselekmény és a hibázás közé korlátot tenni (Chott 2004). A prevencionális jellegú rendszereknél alapvetố célja a hibák kiküszöbölése.

Ennek egyik legkézenfekvő́bb megvalósulása a társadalomban a különbözó a hibák negatív konzekvenciáit is szerepeltető szabályrendszerek, mint például a büntetố törvények közreadása. Ami történhet rásban vagy mint korábbi társadalmakban a konzekvenciák nyilvános végrehajtása, illetve elszenvedése útján, ami ugye csak nézőpont kérdése. Első olvasatra a közreadás e két formája triviális és nem igényel további magyarázatot. Viszont ha abból indulunk ki, hogy amíg a régi társadalmak tagjainak analfabetizmusa okozta a nem megfelelố információs szintet egy-egy bizonyos szabály tekintetében, addig a ma ervezetekben a túl sok információ okoz hasonló helyzetet. Ezért a régi módszer, a konzekvenciák nyilvános végrehajtása még ma is hatásos közlésmódja lehet a szabályoknak. Gondoljunk csak egy vállalat menedzserére, aki megszegett egy fontos szabályt. Amennyiben ennek tényét és következményeit vállalaton belül megfelelốen kommunikálják, biztosak lehetïnk abban, hogy ez nagyban hozzájábiztosak lehethk absin, hogy ez nagyban hozzajarul a szervezet tanúási folyamatához. De a normák és nem betartásukból fakadó konzekvenciák közreadás nak e modja ceszben jellegén, amiról részletesebben majd a post-defectus résznél lesz szó.

Amennyiben egy szervezetnek bizonyos területeken alapvetố célja a hibák kiküszöbölése, illetve azok hatásainak csökkentése - idốrendi sorrendben -, két konkrét intézkedéskört alkalmazhat: az üzemfolytonosság biztosítási $\left(\mathrm{BCM}^{3}\right)$ tervek és intézkedések, valamint hiba hatásait csökkentố válságkezelésre $\left(\mathrm{DRP}^{4}\right)$ valo felkészülés.

Az üzemfolytonosság-biztosítás területén három dolgot vizsgálunk: Mely folyamatok és alkalmazások, illetve berendezések lehetnek hibaforrások? Mekkor ille ve bé

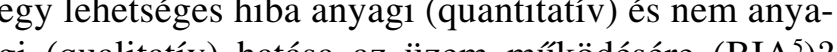
Mekkora a hiba bekövetkezésének valószínúsége Mekkora a

Az idevonatkozó szakirodalom a hiba bekövetkezé si valószínúségének és a hibahatás mértékének függvényében négy stratégiát javasol.

Amennyiben mind a hiba bekövetkezési valószín sége, mind annak hatása alacsony, fogadjuk el a kock zatot. Tekintettel a két változó alacsony várható értéké re, nem szükséges az ilyen jellegú hibák kezelése.

Alacsony hibahatás és magas bekövetkezési valószínűség esetén kezelni kell a kockázatot. A „kezelés" kategóriába esố kockázatok által érintett folyamatokat úgy kell kiigazítani, hogy maga a folyamat lehetőséget adjon a hibahatás azonnali minimalizálására.

Ha a nagy kihatású hiba magas bekövetkezési valószínúséggel párosul, csökkentenünk kell a bekövetke zési valószínúséget vagy a hatás mértékét vagy mindkettôt.

Nagy hatású és magas bekövetkezési valószínús gú lehetséges hibák identifikálásakor azok kezelésé készítsünk terveket. Ezeknek legalább a következő elemeket kell tartalmazniuk: szervezés és tréning, krízis kommunikáció, infrastruktúra, valamint követendő eljárás katasztrófa esetén (8. ábra).

\begin{tabular}{|c|c|c|}
\hline \multicolumn{4}{c}{ Kockázati mátrix } & 8. ábra \\
\hline \multirow{2}{*}{$\begin{array}{c}\text { Bekövet- } \\
\text { kezési } \\
\text { való- } \\
\text { színüség } \\
-\end{array}$} & KEZELÉS & CSÖKKENTÉS \\
\cline { 2 - 3 } & ELFOGADÁS & TERVEZÉS \\
\hline & - & \multicolumn{3}{|c|}{ Hiba kihatása } \\
\hline
\end{tabular}

\section{Post-defectus}

A hibakezelést a hiba bekövetkezése, illetve ha már korábban látszik, hogy be fog következni, akkor ennek szlelése váltja $\mathrm{k}$

A hibakezelés első sorban nem más, mint a hiba ês annak konzekvenciája közé korlátot tenni (Chott, 2004). Ezt az idô mentén tovább bonthatjuk azonnali intézkedésekre és a tanulságok levonására.

Ennek értelmében mikor a hiba megtörtént, két fố dologra összpontosíthatunk: a hiba negatív hatásának csökkentésére, ami pozitív hatásba is átérhet, valamin a hibából való tanulásra kellô idôtávlatból, amikor az összefüggések már jól látszanak.

A válságkezelés nem tartozik jelen dolgozat kutatási fókuszába, de bizonyos értelemben egy válság vagy válság közeli helyzetnek is van pozitívuma egy szervezetre nézve.

Válsághelyzetekre jellemző, hogy standardintézkedésekkel és megszokott stratégiákkal nem lehet kilábalni belôle. Általában a meglévő ismeretek és erőforrások nem elegendóek a helyzet megoldására. A fenti két tulajdonságból adódóan egy szervezet számára egy krízis mindig nagy kihívás.

A válságkezelés gyakorlatilag a pre-defectus fázisra jellemzó üzemfolytonossági elemzéskor kialakított és begyakorlott eszkalációs tervek releváns elemeinek megvalósítása Amennyiben a válság olyan helyzetet teremt, amire a szervezet nem készült fel korábban, úgy a terv elkészítése a leglényegesebbre korlátoź́dik sa végrehajtás gyakorlás nélkül a legrövidebb idôn belül megtörténik.

Ilyen helyzetekben derül ki igazán, hogy a szervezetnek van-e megfelelô reakcióképessége, felkészültsége és szituációs innovációs képesség.

Egy válság természetesen hatással van a szervezeten túl a kisebb csoportokra is. Itt még fokozottabban kerülhet előtérbe a megváltozott helyzetból adódóan a csoport tagjainak viselkedése. A csoport szintjén is igaz, hogy egy válsághelyzetben a régi bevett minták 
kevesek, s az újak megtalálásához hiányzik a megfelelő ismeret, idố, munkaerố-kapacitás és/vagy az anyagi háttér. Az ilyen jellegú szituációk általában magas
stressz-szinttel járnak, hiszen a válság kezelésének, stressz-szinttel járnak, hiszen a válság kezelésének,
illetve nem kezelésének tétjével mindenki tisztában illetve nem kezelésének tétjével mindenki tisztában van. Egy csoport szintjén nyilván nehezebb a hirtelen
elóálló eróforrásigényt lefedni, mint egy szervezetben, ahol általában nagyobbak a tartalékok. Csoportszinten ezért nagyon fontos, hogy a megemelkedet stressz-szint ne az improduktivitás felé mozdítsa el a csoport dinamikáját, hanem inkább segítsen összpontosítani. Tekintettel arra hogy egy (munka)csoporto tositani. Tekintettel arra, hogy egy (munka)csoporto emberek alkotak, akik a mindennapos interakciójuk kolytán kapcsolatban állnak egymással. Némelyil ben a kapcsolat a szabadidóben is intenzív marad. ben a kapcsolat a szabadidôben is intenziv marad. Válsághelyzetben nagyon fontos a csoportot alkotók kapcsolatainak minősége és terhelhetősége. Gondojunk csak Tuckmann „Forming-Storming-NormingPerforming-Adjourding" csapat életciklus modelljére (Bakacsi, 1998: 140-141. o.) (9. ábra).

Tuckmann's Team Cycle

ami ha meg is torpan, rövid idôn belül helyreállítható, s akadályozza a koncentrált teljesítményt.

A magasabb stressz-szint hatása az egyén szintjén Lisa Nolde szerint több fázisban érzékelhetô. Először fokozott ingerlékenység és idegesség, majd depresszió és betegségek is kialakulhatnak. Egy dolog, hogy a munkában a stressztôl szenvedő egyén egyre több hibát vét (Nolde, 2007). A stressz első fázisa már gyengítheti és károsítja a csapaton belüli kapcsolatokat, melynek hatását az elő́bb tárgyaltuk.

Miután az elsó halaszthatatlan feladatokat megoldották, ami többnyire a kármentesítésben merül ki,

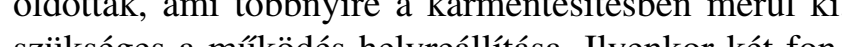
tos tényez áne tos té nyezón érdenes odaffyelni. a tovabbra is fennalló eroforáshianyra, nint peldán a rendelkezésre álló idő, valamint az a lehetőség, hogy az új megoldás nem fétlenül a régin kell, hogy alapuljon. Sót!

Egy sưrú́ erdô aljnövényzete nem kap elég fényt, ezért alig létezik, de ha leég az erdő, megteremtődik a lehetôség, hogy új növényzet foglalja el a régi helyét. Ez a hibázás kapcsán sincs másképp a szociológiai szinte9. ábra ken. Egy esetleges hiba kapcsán, annak mértékétól függően, lehetôség nyílik más, új megoldások alkotására. Igy túl az experimentális hibakultúrán experimentális hibibakultur a prevencionalis hibakultúra is rendelkezik innovációs potenciállal, hiszen a jövoben is inkább a hibák kiküszöbölése a cél, s ami egyszer hibázott, annál már egy jobbra van szüksége. A tanulságok levonása örténhet közvetlen módon, úgy, hogy a hiba elkövetője automatikusan elszenvedi a

Egy meglévő́ csapat esetében elmondható, hogy a hiba konzekvenciáit vagy kívülállóként megfigyelt historming és forming fázisokban többnyire saját magá- bák más által elszenvedett konzekvenciák értelmezésén val foglalkozik, s ezért nem marad energiája a magas kerestiill A konzekvenciák szerepe jelentós a tanulás

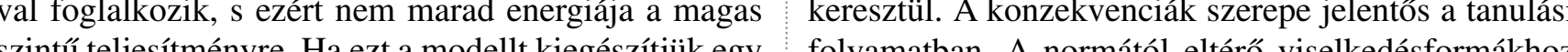
(n) külsố válság hatásával, aminek az eredményeképpen mesto megemelkedik a stressz-szint a csapatban, az lesz a se a büntetés, melynek neveló hatása van. Igaz ennek kérdés, hogy mennyire stabil és mennyire terhelhetón a fordítottja is: elvárt viselkedésnorma mesterségesen csapat tagjai közötti kapcsolat. Amennyiben a csapattagok kapcsolatai nem elég erôsek, a csapat elkezd mag val foglalkozni ahelyett, hogy a megoldandó feladatra, ebben az esetben a halasztást nem tứrô válságkezelésre, koncentráljon. Amennyiben a csapattagok köz kapcsolat nem bírja el a fokozott helyzetet a válságkezeléshez szükséges új ismeretek, stratégiák generálás szenved. Ezért fontos egy egészséges csapatszellem, a dicséret, ami szintén je-

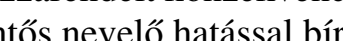

A hibát kellő időtávolságból vizsgálva lehetôségünk an leszúrni belőle a tanulságokat és feldolgozni azokat a jövőre való jobb felkészültség reményében.

A tanulás ebben a folyamatában arra keressük a választ, hogy mi vezetett el a hiba bekövetkezéséhez? S mit tehetünk, hogy a jövő́ben elkerüljük azt?
Az elsố kérdés megválaszolásához érdemes Kess hibaháromszög elemein - szituáció, ok és konzekvencián - túl azok közti összefüggéseket is vizsgál (Kess, 2004).

A második kérdésre való válaszokon alapuló eljarások és normák kiigazítása nem más, mint a chotti êrtelemben korlát emelése egy hiba és a konzekvenciai közé, mielőtt az megtörténne (Chott, 2004).

Túl az összefüggések megértésén és memorizálásán túl jó, ha van lehetôség az ismeretanyag gyakorláśr melynek idóközonténti ismétlése tovább fokozza a tanulás eredményességét.

A fenti ajánlást támasztja alá Hermann Ebbinghaus felejtés görbéje (Ebbinghaus, 1885), mely szerint a felejtésnek exponenciális jellege van, valamint Heinz von Foerster kutatási eredményei, mely szerint minden tudás ellenốrzése a megmaradó tudás tekintetében egy új tanulási szituáció (von Foerester, 1948).

Ezen felül elengedhetetlen a csoportos, illetve szervezeti tudás kialakításához az új ismeretek integrálása a mindennapos folyamatokba. Azon tudáshalmazt, amelyet nem alkalmaznak minden nap, de a szervezet különböző részeiben időközönkén szükségeltetik, központosítva és könnyen hozzáférhetően kell tartani. Ennek a tartásnak két alapvető formáját különböztethetjük meg: a szemályes es információtect péla a szános nagyvallatán példa a számos nagyvállalatnál múkoodó szakértőgá da és belsố tanácsadó cég, amelyek specializált szakértelemmel bíró tagjait a szervezet azon részén vetik be, ahol éppen korlátot kell emelni esetleges hibák
és konzekvenciáik közé, azaz szükséges a speciális szakértelmük. Az információtechnológia területén bekövetkezett rohamos fejlódésének köszönhetően az utóbbira számos példa található a tudásmenedzsment technikai tárházában.

Azok a szervezetek, csapatok és egyének, amelyek/ akik hibákkal szembesültek, krízisekkel találkoztak, azokat legyőzték, többnyire attól megerősödve, megújulva kerülnek ki a kilátástalan helyzetekból (Welch - Welch 2005)

A megújulás forrása a közösen átélt kihívás, melynek eredményeképpen megerósödtek a szereplók közt kapcsolatok, a tapasztalatok beépültek a szervezet ismeretbázisába, s a megszokott minták kényszerú elhagyásának helyén lehetséges innovációk valósultak

Hosszú az út a hibás ébresztóórától a hibakultúra keresztül a szervezeti tanulásig és innovációig.

A hiba definíciójából adódóan egy relatív fogalom. A kérdés, hogy melyik normához viszonyítjuk hibát megvalósító eredményállapotot? Az sem mind- egy, hogy mi a viszonyunk a hibákhoz. Az nem kérdés, ogy megengedjük-e a hibázást, hisz ifjabb Edward A Murphy óta tudjuk, hogy hibák mindig is voltak, s a jövóben is lesznek. Tekintettel arra, hogy a mai világtársadalom tagjai sokkal kiszolgáltatottabbak egymásnak, mint elódeink bármelyike, s a mai technológiákkal a hibák hatása egyre nagyobb, érdemes a prevenciós erőeszítéseken túl arra koncentrálni, hogy mit kezdjünk a hibával. Elemzésekor ne maradjunk meg a hibatünetek szintjén, hanem keressük az összefüggéseket a dimenziók között. A hibakezelés talán legfontosabb kérdése,

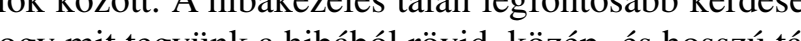
ogy mit tegyink a hibabobl tôvid, kozép- és hosszú tá-

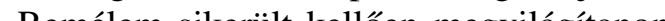

zás pozitív jellegét, s a benne rejlő lahetốśce a hibáamint kedvet csinálni az olvaśnak, hotón a vá hétköznapi csiálni az olvasónak, hogy a hibákat a

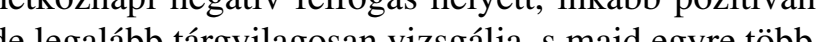
de legalább tárgyilagosan vizsgálja, s majd egyre többször teszi fel a kérdést és találja meg rá a választ: mire jó ez a hiba?

\section{Lábjegyzet} Eredetileg „Etikettierer” - szerző fordítás

Business Continuity Management

Dasiness Impact Analysis

\section{Felhasznált irodalom}

Bakacsi, Gy. (1998): Szervezeti magatartás és vezetés. Közgazdasági és Jogi Könyvkiadó. Budapest

Beck, U. (1986): Risikogesellschaft. Auf dem Weg in eine andere Moderne. Frankfurt a.M.

Chott, P. O. (2004): Ansätze zur Entwicklung einer 'Fehlerkultur'; in: Lernchancen 39/S. 53-56 (7. Jg.)

Dechmann, B. \& Ryffel hristiane (2006): Soziologie im Alltag. Weinheim / München, Juventa Verlag

Durkheim, E. (1996): Über soziale Arbeitsteilung: Studie über die Organisation höhere Gesellschaften. Frankfurt am Main, Suhrkamp

Ebbinghaus, H. (1913): Memory: A Contribution to Experimental Psychology, New York, Teachers College, Columbia University retrieved 2008-03-11 http:// psychclassics.yorku.ca/Ebbinghaus/index.htm

Foerster, H. von (1948): Das Gedächtnis: Eine quantenmechanische Untersuchung, Wien, Franz Deuticke Verlag

Kant, I. (1780): 'Preface'. In The Metaphysical Elements of Ethics. Translated by Thomas Kingsmill Abbott

Kelly, E. (2006): The Basics of Western Philosophy. Greenwood Pres 
Kess, R. (2004): Mehr Fehler - mehr Sicherheit !? Liebl, Karlhans (Ed), Fehler und Lernkultur in der Polizei (19-29). Frankfurt. Verlag für Polizeiwissenschaft Clemens Lorei

Luhmann, N. (2002): Einführung in die Systemtheorie, Heidelberg

Maturana, H. \& Pille B. (2001): Die Fehlerkultur als Grundlage des Lernens. Lernende Organisation, November/Dezember 2001, S. 32-37.

Mensching, A. (2004): Fehler als retrospektive (Un-)Sinnzuweisung innerhalb der Polizei, oder: über die Unentscheidbarkeit dessen, was ein fehler ist. Liebl, Karlhans (Ed), Fehler und Lernkultur in der Polizei (43-56). Frankfurt. Verlag für Polizeiwissenschaft Clemens Lorei

Mill, J.S. (1980): A szabadságról. Haszonelvúség. Magyar Helikon
Nolde, L. (2007): Wenn der Alltag zur Treibjagd wird. Medical Tribune Gesundheit und Medizin, September 2007, 8-13. o.

Orend, B. (2000): War and International Justice: A Kantian Perspective. West Waterloo, Ontario:Wilfrid Laurier University Press

Perzi, N (2003): Die Beneš-Dekrete. Eine europäische Tragödie. NP BUCHVERLAG, Wien

Peters, H. (2004): Zur Soziologie des Fehlers. Liebl, Karlhans (Ed), Fehler und Lernkultur in der Polizei (7-17). Frankfurt. Verlag für Polizeiwissenschaft Clemens Lorei

Tönnies, F. (1887): Gemeinschaft und Gesellschaft. Darmstadt: Wissenschaftliche Buchgesellschaft

Tuckman, B. (1965): Developmental sequence in small groups. Psychological bulletin, 63, 384-399. o.

Welch, J. \& Welch, S. (2005): Winning - Das ist Management. Frankfurt / New York. Campu 